\title{
U⿱宀⿻三丨口
}

\section{Gender Inequality in British and German Universities}

PRITCHARD, R. (2007). Gender Inequality in British and German Universities. COMPARE, 37(5), 651-669. https://doi.org/10.1080/03057920701582582

Link to publication record in Ulster University Research Portal

\section{Published in: \\ COMPARE}

Publication Status:

Published (in print/issue): 01/10/2007

DOI:

10.1080/03057920701582582

\section{Document Version}

Author Accepted version

\section{General rights}

Copyright for the publications made accessible via Ulster University's Research Portal is retained by the author(s) and / or other copyright owners and it is a condition of accessing these publications that users recognise and abide by the legal requirements associated with these rights.

\section{Take down policy}

The Research Portal is Ulster University's institutional repository that provides access to Ulster's research outputs. Every effort has been made to ensure that content in the Research Portal does not infringe any person's rights, or applicable UK laws. If you discover content in the Research Portal that you believe breaches copyright or violates any law, please contact pure-support@ulster.ac.uk. 


\section{Journal: Compare}

Paper: 258113

Title: Gender inequality in British and German universities

\section{Dear Author}

During the preparation of your manuscript for publication, the questions listed below have arisen. Please attend to these matters and return this form with your proof. Many thanks for your assistance

\begin{tabular}{|c|c|c|}
\hline $\begin{array}{l}\text { Query } \\
\text { Reference }\end{array}$ & Query & Remark \\
\hline 1 & $\begin{array}{l}\text { Bett Report } 1999 \text { - Please give } \\
\text { the name and initial(s) of the } \\
\text { writer of the report or the organi- } \\
\text { sation that originated it. }\end{array}$ & \\
\hline 2 & $\begin{array}{l}\text { Grundgesetz } 1998 \text { is not listed in } \\
\text { References. Please supply refer- } \\
\text { ence or delete text citation. }\end{array}$ & \\
\hline 3 & $\begin{array}{l}\text { Deutschlandvertrag } 1990- \\
\text { Please give the name of the } \\
\text { organisation that originated the } \\
\text { treaty. }\end{array}$ & \\
\hline 4 & $\begin{array}{l}\text { CEWS } 2005 \text { here, } 2006 \text { in } \\
\text { References. Which is correct? }\end{array}$ & \\
\hline 5 & $\begin{array}{l}\text { Please give HSP in full at first } \\
\text { mention with the abbreviation in } \\
\text { parentheses. }\end{array}$ & \\
\hline 6 & Please give HWP in full. & \\
\hline 7 & $\begin{array}{l}\text { Bologna Agreement } 1999- \\
\text { Please give the name of the } \\
\text { organisation that originated the } \\
\text { agreement. }\end{array}$ & \\
\hline 8 & $\begin{array}{l}\text { Bett Report (1999) - Please give } \\
\text { the name and initial(s) of the } \\
\text { writer of the report or the organi- } \\
\text { sation that originated it. }\end{array}$ & \\
\hline
\end{tabular}




\begin{tabular}{|c|c|c|}
\hline 9 & $\begin{array}{l}\text { Bologna Agreement (1999) - } \\
\text { Please give the name of the } \\
\text { organisation that originated the } \\
\text { agreement. }\end{array}$ & \\
\hline 10 & $\begin{array}{l}\text { Dalhoff et al. (2002) - Please } \\
\text { supply volume number. If this } \\
\text { publication does not have volume } \\
\text { numbers use year. }\end{array}$ & \\
\hline 11 & $\begin{array}{l}\text { Deutscher Bundestag } 1998 \text { is not } \\
\text { cited in text. Please insert rele- } \\
\text { vant text citation or delete refer- } \\
\text { ence. }\end{array}$ & \\
\hline 12 & $\begin{array}{l}\text { Deutscher Bundestag ( } 2004)- \\
\text { Please supply place of publica- } \\
\text { tion. }\end{array}$ & \\
\hline 13 & $\begin{array}{l}\text { Färber }(2000) \text { - Is this Frankfurt } \\
\text { am Main or Frankfurt am der } \\
\text { Oder? }\end{array}$ & \\
\hline 14 & $\begin{array}{l}\text { Krais }(2006) \text { - Please complete } \\
\text { reference with volume, issue and } \\
\text { page numbers. }\end{array}$ & \\
\hline 15 & $\begin{array}{l}\text { Loder and Eley (1998) - Day and } \\
\text { month should be given for weekly } \\
\text { publications. }\end{array}$ & \\
\hline 16 & $\begin{array}{l}\text { Her Majesty's Government (1998) } \\
\text { - Please give date web site } \\
\text { accessed. }\end{array}$ & \\
\hline 17 & $\begin{array}{l}\text { Her Majesty's Government } 1998 \\
\text { (Northern Ireland act) is not cited } \\
\text { in text. Please insert relevant text } \\
\text { citation or delete reference. }\end{array}$ & \\
\hline 18 & $\begin{array}{l}\text { Saunderson (2006) - Please give } \\
\text { town/city rather than county in } \\
\text { which published. }\end{array}$ & \\
\hline 19 & $\begin{array}{l}\text { Zimmer (2003) - Please supply } \\
\text { place of publication. }\end{array}$ & \\
\hline
\end{tabular}


Vol. 37, No. 5, October 2007, pp. 651-669

\title{
Gender inequality in British and German universities
}

\author{
Rosalind Pritchard \\ University of Ulster, UK
}

Gender inequality exists within higher education in the UK and Germany. In the UK only $15.3 \%$ of professors in pre- and post-1992 universities were women (2003), whilst in Germany only 8.6\% attained the highest grade of professorship (2003). The research uses existing data sets combined with theoretical constructs to investigate the reasons for gender inequality in British and German higher education. It examines and evaluates equality legislation in action, it teases out the social and epistemological aspects of gendered behaviour within the work situation of female academics and it investigates why female academics have a more difficult time gaining promotion in German than in British universities.

Keywords: Gender inequality; Higher education; UK; Germany; Feminism; Academic career structure

\section{Introduction}

Gender inequality is a ubiquitous and omnipresent problem within higher education. Typically women are under-represented in professorial grades, in senior management and in the highest echelons of administration, but are over-represented at lower levels, where employment is often temporary, the monetary rewards small and the job position precarious. Brooks (1997) showed that feminism takes different forms in different countries and Deem (1981) showed that the position of women is linked with state policy and ideology. Why do particular elements work well or badly, what are the barriers to the achievement of greater gender equality and what can be disseminated in the way of good practice? The purpose of the present paper is to study two countries of the European Union, the UK and Germany with the

- to compare facts and figures relating to the position of academic women;

- to consider the reasons for these trends and relate them to concepts of equality and gender justice;

- to present the main characteristics of remedial national legislation pertaining to gender equality and to comment critically upon it.

* School f Education, University of Ulster, Cromore Road, Coleraine, Ulster BT52 1SA, UK. Email: r.prichard@ulster.ac.uk

ISSN 0305-7925 (print)/ISSN 1469-3623 (online)/07/050651-19

(C) 2007 British Association for International and Comparative Education

DOI: $10.1080 / 03057920701582582$ 
The author is a British national with a research background in comparative and international education, a long-standing interest in Germany and knowledge of the German language. The British and German models are internationally seminal and, therefore, worthy of study. The UK higher education system is sometimes referred to as the 'Anglo-Saxon model' and in recent years, because of its vigorous espousal of neo-liberalism, has aroused worldwide interest. The German model, often referred to as 'Humboldtian' after Wilhelm von Humboldt, co-founder of the University of Berlin, is the model for many countries in East Central Europe and for some American universities, like Johns Hopkins.

\section{Aspects of the study of gender}

Theorists distinguish between a number of approaches to the study of gender, of which the main ones are liberal feminism, socialist/Marxist feminism and radical feminism (Heywood, 1992; Bradley, 1996). Liberal feminists focus on the 15 relationship between education and the state, relying on legal and institutional arrangements to promote equality, but doing little to question the social assumptions underneath (Bradley, 1996, p.86). They believe that all individuals are of equal worth and should enjoy an equal opportunity to participate in public life, but they seek to open up competition rather than challenging the nature of society itself (Heywood, 1992, p. 230). Socialist or Marxist feminists focus on economic aspects of inequality, in particular the exploitation of labour within a capitalist mode of production, and regard gender domination as subordinate to other forms of domination, such as class. They do not believe that giving equal rights will necessarily abolish inequality, because they regard inequality as being rooted in the social and economic structure itself, which nothing short of a revolution will change (Heywood, 1992, p. 231). East German academic women in the formerly Communist part of Germany were socialized into society and academia under this dogma. Gender acquired a different meaning in the East and East German women had to learn to re-build their personal and academic lives within a different regime after the fall of the Berlin Wall, having been accustomed within the Communist regime to expect working motherhood and lavish childcare facilities (Pritchard, 2003). Radical feminism is preoccupied with male violence and societal domination and seeks to develop a theory of sexual repression by uncovering the influence of patriarchy on personal, social and sexual existence (Heywood, 1992, p. 235ff.). In its more extreme form this philosophy regards men as the enemy and calls for revolutionary change involving the destruction of the family: to be truly equal women need to be liberated from childcare and child-bearing. Critics of radical feminism point out that gender inequality obscures other forms of injustice, such as racial and class inequality, and Jones (1993, p. 161) asserted that the social order within which femininity is constructed cannot be seen as 'uniformly repressed'.

It is difficult to make exact British/German comparisons of female representation at various levels of academic life because the career structures are different. The UK has a structure of Lecturer, Senior Lecturer or Reader, with Professorship as the 
0 highpoint of a career. Crucially, the non-professorial as well as the professorial grades usually carry security of tenure. Promotion within the British system depends much less than the German system upon qualification or credentialism. It is possible to become a Vice-Chancellor without a doctorate, and even possible to be a professor without a doctorate. Traditionally, the main career grade in Germany has been that of full professor. This is not, as in the UK, the apogee of one's career. It is likely to be the first tenured post that the incumbent achieves as the result of a long period of academic preparation and apprenticeship. The system relies very much upon qualifications for the job. The normal requirement for promotion to a Chair has been not just a doctorate (Promotion) but also a post-doctoral thesis 10 (Habilitation). ${ }^{1}$ This is usually not completed until about age 40, with the result that German academics embark upon their mainstream career at a much older age than in other countries. The payment categories for the professoriate have been organized into ' $\mathrm{C}$ ' designations, with $\mathrm{C} 2$ as fixed term, then $\mathrm{C} 3$ and $\mathrm{C} 4$, with the latter being the highest category of all. As the result of a recent law new 'W'

15 designations have been introduced and the career structure has been modified. More will be said about these changes towards the end of the present paper.

\section{Methodological approach}

Mantz Yorke (2006), in an article entitled Gold in them there hills?, pointed out that vast statistical resources are available to researchers and that these are very much under-utilized. The present study is, therefore, based upon the use of existing data sets from a variety of sources, some retrieved directly as a result of the author's requests to statistical and research agencies. They are synthesized in tables based upon a conceptual framework developed for the study. It was not always as easy as one might think to match the data across cultures: for example, no figures in Germany were available for pay differentials between men and women academics, although these are available for the UK and are clearly very relevant to equality issues. ${ }^{2}$ Conversely, in the UK the Higher Education Statistics Agency (HESA)

30 could not give the percentage of female holders of secondary school certificates qualifying for entry to university, although it has been calculated in Germany as $53.5 \%$ (Bundesministerium für Bildung und Forschung [BMBF], 2001). The figures were culled from several sources, which are listed underneath the tables, and because of this diversity the years upon which they are based sometimes vary. They 35 do, however, indicate clear cross-national trends and are followed by a theoretical analysis to account for national differences. These are discussed first in terms of epistemology, second in terms of social factors and third in terms of legal provisions. The article concludes with a section that attempts to evaluate the relative merits of legislation in each country.

\section{The pathology of gender inequality in higher education}

It is pertinent to ask what the criteria of equality in academe are. They vary according to one's perspective, usually including pay, promotion, numerical 
0 representation and tenure of employment. In Brooks' (1997) study equality was often defined as gaining a permanent post. It could also be defined as a step up to the next rank once tenure has been achieved, but there seems to be a consensus in the literature that the 'gold standard' of equality is the ability of women to reach the rank of professor (Färber, 2001, p. 144). Some statistics on the position and achievements of female academics in each country are shown in Tables 1-4.

Despite the fact that in Germany $53.5 \%$ of female school leavers are qualified to enter higher education, the percentage of female university students was under $50 \%$ in 2002. The proportion of female university graduates is about 10 percentage points higher in the UK than in Germany. Although female students currently constitute a 10 high proportion of the student population in both countries, the top management positions are mostly taken by men. Female students are clustered in a small number

Table 1 . Women as a percentage of aggregated genders (\%)

\begin{tabular}{llr}
\hline & UK & Germany \\
\hline Female students at universities (2002) & 53.8 & 47.4 \\
University graduates (2004) & 58 & 48.7 \\
Female academic staff at higher education institutions (2004) & 41.2 & 29.1 \\
Full professorships (UK) or C4 and W3 (highest German grade) (2003) & 15.3 & 8.6 \\
All grades of professorship (2003) & 15.3 & 12.5 \\
Senior lectureship (UK only) & 26 & N/A \\
Management & 46 & 15.2 \\
\hline
\end{tabular}

Sources: AUT, October 2005; HESA, data request 2006 (HESA formal disclaimer: 'HESA cannot accept responsibility for any inferences or conclusions derived from the data by third parties'); Centre of Excellence Women and Science, Bonn, data request 2006; http:// www.cews.org/statistik/.

Table 2. Women doing technical and mathematical subjects (\%)

\begin{tabular}{lcc}
\hline & UK & Germany \\
\hline Female students doing science, mathematics and computing (2002) & 39.2 & 33.0 \\
Female students doing engineering, manufacturing and construction & 15.9 & 18.9 \\
$(2002)$ & & \\
\hline
\end{tabular}

Source: Office for Official Publications of the European Communities (2005).

Table 3. Women obtaining top academic qualifications (\%)

\begin{tabular}{lcc}
\hline & UK & German \\
\hline Women doctoral graduates (2003) & 41.5 & 37.9 \\
Habilitation (post-doctoral thesis) (1999-2001) & N/A & 17.8 \\
Habilitation (2003) & N/A & 22.0 \\
\hline
\end{tabular}

Source: Office for Official Publications of the European Communities (2005). 


\begin{tabular}{lcc}
\hline & UK & Germany \\
\hline Humanities and arts & 45.9 & 49.5 \\
Science, mathematics and computing & 41.9 & 29.9 \\
Agriculture & 45.2 & 54.3 \\
Health and social services & 50.0 & 43.5 \\
Engineering, manufacturing and construction & 19.6 & 11.4 \\
Social sciences, business and law & 42.2 & 34.5 \\
Total & 41.5 & 37.9 \\
\hline
\end{tabular}

of fields and numbers in the hard sciences are small. It is likely that future academics will come from the cohort of doctorates and it is clear that the UK had more female students and Ph.D. holders in science, mathematics and computing than Germany (2003); the UK also had more in engineering, manufacturing and construction. These figures are broadly in keeping with European trends: a study entitled Women in European universities (Zimmer, 2003) reported that female students are clustered in a small number of academic fields and disciplines, particularly in the humanities and social sciences. The choice of academic discipline has far-reaching implications for the status and life chances of women in academia, and will be discussed further below. It is notable that in the UK $26 \%$ of senior lecturers are female. Although these staff do not bear the title professor, they are in a tenured and promoted grade by comparison with the German C2 grade. They could be regarded as approaching, although not reaching, grade C3 in Germany and their grade constitutes a helpful 'ladder' in upward mobility.

In the UK almost half the women in 'pre-1992 universities' are on the most junior lecturer grade, and only $14 \%$ of professors are women. The proportion of professorships varies according to institution. Thus, Morley (2003, p. 151) pointed out that only $6 \%$ of professors at the highly prestigious University of Cambridge are women. Some, especially in 'new' (post-1992) institutions, receive the title of professor without the remuneration, and Halvorsen, (2002a, 2002b) estimated that it will take 68 years at the present rate of progress before half the professoriate is female. He also estimated that an immediate cash injection of between $£ 200$ million and $£ 400$ million would be required to eliminate the salary differential. According to the British Association of University Teachers (AUT), men are 1.5 times more likely to be awarded discretionary pay (AUT, 2006b; Hunt, 2006). The average female academic will earn 4-5 years less salary than the average male colleague for the same number of hours worked. This is largely because women are at lower grades and a disproportionate number are in untenured or part-time positions and are located in post-1992 ('new') universities (Bett Report, 1999), however, within grades the pay difference is slight (West \& Lyon, 1995, p.53; AUT, 2005). In Germany the proportions of women in the highest professorial grades have been rising continuously since 1990 and doubled between 1993 and 2004. However, a notional 
0 target of $20 \%$ female professors and $40 \%$ female management by 2002 (see BMBF, 2001) had still not been reached in 2006 and the proportion of women in leading positions within free-standing research institutes was only $7.7 \%$ in 2004 (BundLänder-Kommission, 2005, p. 8). The pursuit of an academic career is demanding and all-absorbing, to the point that in Germany, as in the UK, many women are without partners and children. Thus Bagilhole's (1993) UK research showed that only $56 \%$ of women academics were married or had a partner and only $30 \%$ had children. German studies too (see, for example, Zentrum fur Umfragen, Methoden und Analysen, 2004) demonstrate that the higher a woman's academic qualifications, the less likely she is to be a mother. Färber (2000) quoted research indicating that in the FRG 53\% of female professors did not live with a partner and over half of these women had no children, whereas only $12 \%$ of male counterparts were childless, so women make the sacrifice of not founding families whereas men do not.

Accompanying these statistics is a syndrome of female underachievement. Men are twice as likely to be entered in the UK Research Assessment Exercise (RAE) as women and of the 43,000 academics recorded as 'research active' in the 2001 RAE only $25 \%$ were women (AUT, 2005). Women in the UK submit fewer research grant applications (Loder \& Eley, 1998). Wilson (1986, p. 80) discovered that $42 \%$ of women academics had not presented conference papers in the previous three years. Brooks (1997, p. 43) found in her study that British academic women were not as productive as men: fewer of them had a Ph.D. and fewer published. Women have various strategies for distancing themselves from the rat-race. Thus, West and Lyon (1995, p. 65) claimed that those who refuse to compete in a meritocratic culture may be putting up a form of resistance. They also speculated that competition between the genders may be a zero-sum game: if marginalized groups are to be fully incorporated, there must be a relinquishing of power and control by those in less favoured positions. In the gender research conducted by Wilson (1986) $68 \%$ claimed that they were not subject to any form of discrimination, but Wilson nevertheless believeed that discrimination is often insidious and difficult to diagnose and that decisions are still made in a hierarchical, undemocratic way. In a similar vein, Morley (2003, p. 155) quoted research indicating that women needed to be two-and-a-half times more productive than men in terms of publications to achieve the same ratings as men for scientific competence. Be that as it may, an attempt must now be made to explain these indices of inequality and under-performance. The following section will discuss the reasons for the pathology of gender inequality in epistemological and social terms, in keeping with recent approaches to the study of feminism.

\section{Possible reasons for gender inequality}

Epistemology and gender

It is, of course, dangerous to make generalizations about gender and ways of knowing. For this reason Luttrell (1989) cautioned against an essentialist approach which claims that women all share a singular developmental experience, and 
0 Walkerdine (1989, p. 205) argued that patriarchy is not a monolithic force in the socialization of girls. However, an important body of scholarship postulates links between gender and academic discipline which can be distilled into the four tendentious postulates set out below.

Gender-related ways of 'knowing' exist. It is argued that different personal attributes are needed for different disciplines and that these attributes may be gender-related. Reybold (2002) proposed an association between psychology and the culture of knowing: cognition is situated in a context of race, class and gender. Wolffensperger (1993, pp.38-39) believed that the supposed female attributes of conformity, passivity and submission contrast with the detachment and rivalry needed for the pursuit of science. The theme of competition was also emphasized by Krais and coworkers (Krais et al., 1997; Krais, 2002), who, following Ong (1981), used the word 'agonal' to describe it (from the Greek agōn, meaning contest). These concepts were linked with work ethos by Belensky et al. (1986), who distinguished between 'connected knowing' and 'separate knowing'. The former involves an empathetic orientation towards reasoning, whereas the latter involves challenge, doubt and critical thinking. It is a more individual, independent form of reasoning compared with 'inter-individual' patterns, which are in women's 'comfort zone'. However, particularly in Germany, there is a conviction that female academics have better chances to progress professionally if they are in subjects where there is a strong methodological core and clear concepts of what constitutes excellence and rigor (Löther, personal communication, 2006).

Men make the rules and feminists challenge them. Jackson (2002, p. 20) pointed out that men still hold the vast majority of senior research and senior lecturer posts and that it is mostly they who determine what is 'good' research and set the rules. She claimed that what determines 'good research practice' is guided by a male academic culture and institutional discrimination against women. The traditionally maledominated disciplines, such as medicine, engineering and the physical sciences, receive disproportionately large allocations of funding; this operates to the disadvantage of women, many of whom are drawn to interdisciplinary research. She stated: 'The gatekeepers of the academy ensure that the work of women academics remains undervalued, with severe effects on their career opportunities and development' (Jackson, 2002, p. 20). Yet there are different 'knowledges' about the same thing, for knowledge is always grounded in a point of view, and the feminist framework derives its distinctiveness from the context and frame of reference employed. Feminist theory is critical of the claim of traditional knowledge to neutrality. Jackson (2002, p. 28) quoted with approval a statement by the barrister Helena Kennedy: 'the very conceptions of knowledge and excellence have to be 40 challenged'.

Men tend to occupy the high status and women the low status subject areas. As we have seen above, women are conspicuously under-represented in science, technology and engineering, in both the UK and Germany. This leads to patterns of vertical 
0 segregation. Entwistle (2005, pp.77-79) pointed out that because of their interpersonal orientation, women tend to cluster in the social sciences and humanities, which are 'contested' knowledge. The disciplines in which many women are located do not have a stable epistemic core, unlike mathematics and science, and those academic domains that shift from knowledge to the development of skills may have the concomitant effect of reducing the academic prestige of their proponents. The interaction between low status fields and high levels of what he called 'peripheral participation' (e.g. placement or networking) can lead to female neglect of research and to a downward spiral for women within academia. Yanoshak and Delplato (1993, p. 287) believed that endorsing the traditional disciplinary

10 categories replicates their old hierarchical value, and 'fails to dislodge the privileging function of grand metanarratives about great Western men'. They challenged the methods used to construct and name knowledge, as practiced in the traditional academy, and they sought to politicize interdisciplinary study by claiming that women's oppression is visible in all aspects of society. Although their stance was frankly 'oppositional', other scholars (see, for example, Jones, 1993) believe that the construction of new subject positions that resist the dominant forms will lead to an increase in the number of 'ways of being' available, especially for girls.

Women are subject to the 'curse' of caring. It has been noted by Hey and Bradford (2004) that females find it difficult to let go of being 'caring' and may 'do femininity' in the service of the corporate university (Hey \& Bradford, 2004, p. 699). In the evaluation of higher education teaching staff by students there is evidence (Carson, 2001) that 'sexist' students expect women academics to adopt a feminine style in order to be acceptable. This is necessary for respectability and popularity but, paradoxically, being 'approachable' sometimes leads to a loss of academic credibility, and devoting a large amount of time to teaching-related issues causes a neglect of research and thus a failure to behave strategically. Women higher education teachers have to work hard to prove their academic authority, which is taken for granted by male lecturers, but they often carry heavier teaching, research and counseling responsibilities than do their male colleagues (Carson, 2001, p. 351). The expectation of typical femininity has also been highlighted in European comparisons of women in science, where a key research finding is that the combination of being tough but at the same time charming is essential to professional success. In order to be accepted in the academy, and also in the scientific community, women have to fulfil a 'gender contract' by being 'nice and charming' (Zimmer, 2003, p. 14). But being 'caring' can be important for men too, and Walsh (2002, p. 38) believed that men's competitive behaviour, as expected of their gender and sexuality, interferes with 'their abilities to do their jobs in a caring, responsible and skilful manner'.

Since women seem to gravitate towards subject areas and organizational activities that result in lesser prestige and expectation of success, it is important to attract them to science and technology, where the potential rewards are greater. Both the $\mathrm{UK}$ and Germany have designed arrangements for this purpose: for example, the 
0 Athena Project (Bebbington, 2002) and SET Fair (Greenfield et al., 2002) in the former and programmes like 'Femtec' (www.femtec-network.de) in the latter.

\section{The social dimension: structures and sponsors}

In both Germany and the UK it has been pointed out that the patronage system for sponsored mobility within the higher education sector operates to the disadvantage of women, and at the department level can be a crucial barrier. Heward (1994, p. 260) claimed that it is a source of discrimination to those who seek promotion to senior academic status. Male scholars tend to feel more comfortable with other males, be 10 they staff or students, and many bonding opportunities are associated with sport, drinking, pubs and the Senior Common Room, where women may feel uncomfortable. Bourdieu asserted that such activities are crucial to society. They are 'games' of honour and war or, in advanced societies, the prestigious fields of the arts, politics, business and science, and they are all-important because they involve 'world-making' (Bourdieu, 1994, p. 137; Krais, 2006). Women have fewer good networks and role models than men, and this fact alone can militate against their advancement (Bagilhole, 2002, p. 50). Morley (2003, p. 158) claimed that they are more vulnerable to bullying, manipulation and the extraction of compliance. In Germany sponsorship interacts with a daunting career structure to eliminate many women long after they have launched themselves upon the road-they hope-to a professorship. We have seen above that only $7.7 \%$ of free-standing research institute leaders are women. The most important of these institutes are the Helmholtz, the Max-Planck, the Fraunhofer and the Leibniz Societies, and it was women's failure to progress in them that prompted Krais et al. (1997) to research into the reasons for such a state of affairs.

Krais et al. (1997) performed a qualitative and quantitative study involving nine Max-Planck Institutes (MPIs) where there are very few women in senior positions. Although the MPIs are outside the university system, the researchers regarded their results as valid and typical for German academe as a whole. They attended particularly to the social dimensions that result in the 'disappearance' of promising women from senior positions. Social action follows its own logic and when it seems or feels like second nature it has become a 'habitus', in the sense propounded by Bourdieu. Judgements made about whether or not a person has the right habitus result in a cooling-out process that excludes a disproportionate number of women. For promotion the aspiring academic needs sponsorship by a professor, who may be a director of an institute, and as Krais pointed out the personality of the director is of decisive importance. His persona is in the mould of the Great Man (rarely Woman) upon whom the younger scholars are dependent and upon whose goodwill they rely for mentoring and support. In their own career interests those who are dominated may sometimes collude with that domination. They live in economically precarious circumstances until their 40s, and during this protracted period of dependence they work up to 10-14 hours a day. Many females pay the penalty of renouncing or postponing family life and children, although this is less likely with men. For all the scholars, both male and female, time, space and money are all in short supply, and this 
0 'culture of scarcity' too has a selective function. The intermediate rungs on the career ladder, such as associate or assistant professor, are missing and, as Krais (2002, p. 410) pointed out, a woman (or a man) has to 'leap' from a position of relative dependency to the top rank. There are, she stated, 'no formally regulated transparent structures for junior academics'. There is no possibility of progressing step by step and minimizing the risk of career failure. It is all or nothing. Krais et al. (1997, p. 30) wrote:

The doctorate is the last possible 'point of no return' for a decision to get out of research. Only up to that point are other professional options possible. After the $\mathrm{PhD}$, far-reaching life-course decisions must be made and, in terms of time, these pressurize women more than men in a structural career constellation over which they themselves have almost no control. The unpredictability and the high danger of failure of an academic career in Germany affect women much more than men.

The Habilitation is the eye of the needle through which all must pass. However, women in the MPIs often felt that what they say was disregarded or not taken seriously. They may even be subjected to 'symbolic violence', deprived of their proper titles, made to feel that they do not belong, until finally they vote themselves out and disappear. Krais et al. (1997) called for the abolition of the Habilitation and the introduction of more modest, less well paid posts (e.g. assistant professor) as stages on the road to the big professorship.

The career structure in German academia is indeed changing, and the ways in which this might affect the academic profession will be discussed below. The next section will be devoted to legal attempts to promote equality and reduce discrimination. It is true, as Walsh (2002, p. 41) said, that 'The philosophical, political and ethical questions raised by equal opportunities are incapable of being illuminated or much advanced by legislation', however, although the law may be a blunt tool for ameliorating the situation, it is still important.

\section{Legal provisions for gender equality}

Gender law-making needs to become embedded within higher education and the success of that embedding depends on factors at different levels: legal, cultural, economic and political (Färber, 2001, p. 147). Each country has different strengths at different levels, and Heward (1994, p. 257) claimed that it is the interaction of process and structure that explains the perseverance of the 'glass ceiling' preventing women's promotion. The UK is of course a unitary state in which national legislation demands conformity, whereas Germany is a federal state in which national legislation constitutes a framework that is interpreted by each state (Land) according to political constellation and local circumstances. In what follows, an outline will be given of recent legal attempts to combat inequality.

\section{The United Kingdom}

In Great Britain a new Equality Act gained royal assent on 16 February 2006. As in Northern Ireland, it will eventually subsume the existing equality commissions and will 
0 cover England, Scotland and Wales. It provides for the establishment of a Commission for Equality and Human Rights (CEHR), a single integrated body to underpin legislation on race, gender, disability, religion or belief, sexual orientation, age and human rights. The Equality Act will require public authorities to pay due regard to promoting gender equality and eliminating sex discrimination. This means that higher education institutions (HEIs) and other public sector employers will have to take account of the different needs of men and women to ensure equality of opportunity when preparing policies or providing services. HEIs will need to set their own gender equality goals in consultation with their employees and service users and take action to achieve them. Equality targets are set by comparing monitoring data with expected 10 figures based on labour availability, catchment areas and levels of qualifications and are agreed with the Commission(s). There are no sanctions in terms of fines.

The Act contains a 'gender duty' that requires public authorities to eliminate discrimination and promote equality of opportunity between men and women. The detailed proposals, drawn up in consultation with government departments, the wider public sector and external stakeholders, centre around three main components obliging public authorities to:

- identify and implement specific gender equality goals;

- develop and publish an equal pay policy statement;

- assess the impact of changes in policies and services on men and women, allowing negative effects to be mitigated.

Initially education was not covered within the proposals, but after campaigning by education unions the Government announced in December that the specific duties would be extended to the education sector. The Association of University Teachers (AUT, 2006a) (now subsumed in the University and College Union) wanted the Higher Education Funding Councils to take responsibility for ensuring compliance within the sector and fixing penalties if institutions did not comply. It has called for a strategic approach based on enforceable duties that prompt priorities and coordinated action. It insists that the CEHR needs to be well resourced to ensure it can carry out its duties and that it must clarify how successful implementation will be monitored, e.g. by the number of published gender equality schemes or by outcomes such as a significant closing of the pay gap over the next five years? Equality impact assessments are already carried out in Northern Ireland by commissioning and/or monitoring information and community consultation, and similar arrangements will be introduced in Great Britain. If a policy, service or project is identified in pre-screening it will undergo a more wide-ranging assessment, however, although many universities do have equality officers, crucially there are no sanctions to punish non-compliance or rewards to recognize achievement. ${ }^{3}$

\section{Germany}

In Germany equality goals are enshrined in the Basic Law (tantamount to a Constitution) of which Article 3 states that all are equal before the law, that men and 
0 women have equal rights and that the state is to work towards the removal of existing disadvantages (see Grundgesetz, 1998). No one is to be privileged or disadvantaged because of his or her gender, genealogy, race, language, home, origins, belief, religious or political views and no one is to be disadvantaged because of disability. Article 33 (2) states that all Germans have equal access to public positions according to their aptitude, ability and subject-related achievements. Article 31 (para. 1) of the Unification Treaty (Deutschlandvertrag, 1990) states that it is the task of all German law-makers to enact laws for equality between men and women. In keeping with these provisions, the Federal Framework Law for Higher Education (Deutscher Bundestag, 2004) also contains equality goals. The HEIs are enjoined to strive for the removal of inequality between men and women, as the Basic Law states, and the federal Länder (the 16 states of the Germany) are to enact legislation to this effect. Having due regard for suitability, aptitude and subject competence (as stated in the Basic Law, Article 33, para. 2), women are to receive favourable consideration.

The concept of 'mainstreaming' equality is explicit government policy in Germany (see BMBF, 2002). Mainstreaming moves beyond 'equal treatment' and 'positive action', where both have their down sides, to one in which equality is no longer perceived as being in the interests of a marginalized group, but as being the responsibility of the whole university community (Färber, 2000, p. 262). It is concerned with both men and women and is not just a way of 'getting women on' (Dalhoff et al., 2002). As Rees (1998, p.30) explained, equal treatment 'simply removes the more obvious structural barriers to individuals' access to systems which themselves are shaped by [patriarchal] patterns of dominance and oppression'. Equality of opportunity does not necessarily lead to equality of outcome, and it is quite possible for organizations to reproduce their cultures even when equal treatment policies of various strengths are in place (Rees, 1998, p. 34). Positive action and positive discrimination also have deficiencies. They rely on stratagems such as quotas, assertiveness training and all-female shortlists in order to create a level playing field at the start, but the systems, values, structures and the very notion of merit itself are left unquestioned. Yet 'merit' is not really objective or value free, after all, it derives from the values of those in positions of power. Mainstreaming, in contrast, is an attempt 'to make equal opportunities the basis of entire policies and the task of those in positions of responsibility' (BMBF, 2002, p. 20). Concern with equality issues needs to be 'owned' by everyone within the institution and embedded at all levels from top to bottom. It involves a paradigm shift in culture, rules and operations and involves identifying 'those hidden, unrecognized and unremarked ways in which systems and structures are biased in favor of men' (Rees, 1998, p. 189).

Under mainstreaming equal opportunity thinking needs to be integrated from the very beginning. One way in which this is done in Germany is by means of Women's Representatives (Frauenbeauftragte) who operate differently to Equality Officers in the UK. ${ }^{4}$ Various models exist. The University of Göttingen, for example, operates as follows. There exist central University Women's Representatives and local Women's Representatives who are elected, one per faculty. They come together 
0 collectively for consultation as a university-wide Women's Committee. There are about 16 such representatives across the university as a whole, and they are paid a modest sum of money to do the work. To an outsider one surprising aspect of the set-up is that a Faculty Women's Representative could be a student, specially trained for the task (although she might also be a serving academic). Part of her power relates to the appointment of professors. She can influence the text of a job specification, view job applications, be present at interviews and has the right to check all the job offer recommendations. If there is reason for concern (lack of transparency, injustice or a misuse of power) she will take the matter to a more senior colleague (the University Women's Representative) who can formally object to the Senate's decision to offer that job to a particular person. It is a statutory requirement that the success of the German HEIs in promoting women be regularly evaluated and in most Länder this success in achieving equality targets is linked to formula funding. ${ }^{5}$ If the universities miss their equality targets they may lose money. This is a powerful sanction and it is one called for in the UK by Saunderson (2006, p. 194), who believes that policy-makers should clearly designate accountability from an HEI level through the funding councils to government level and impose penalties where breaches occur.

The Centre of Excellence Women and Science (CEWS), an independent although government funded institution, specializes in research and data collection on women in academia. It has produced a ranking or 'league table' of German HEIs according to their success in promoting gender equality (CEWS, 2005). This exercise was carried out for the first time in 2003 and involved evaluation of how well women perform in relation to doctorates, Habilitation theses, students and academic personnel. The top Bundesländer were Berlin, Hamburg, Lower Saxony and Brandenburg. The top ranking universities were the Free University of Berlin, the Johann Wolfgang Goethe University, Frankfurt am Main and the Georg August University, Göttingen. These are all large institutions. It had been half expected that large universities would perform poorly in these equality ratings, but this turned out not to be the case. Equal opportunity policies can be carried out just as effectively in large as in small universities.

\section{Concluding observations}

There are obvious differences in orientation between the British and German legislation. Both countries want and need women's expertise to be an important contribution to the labour market. However, as Brooks (1997, pp. 56-57) pointed out, there is a huge gulf between policy and practice, and there is no guarantee that equal opportunity legislation will improve the quality of academic relations. She wrote: 'the existence of an equal opportunities policy without an accompanying set of practices is merely a public relations exercise'. Bagilhole (2001, p. 197) stated that the guiding principle of the British initiatives is persuasion. In Germany, however, the formula funding link to equality targets contains an element of compulsion and the legislation moves beyond prohibiting discrimination against women to actively 
0 promoting their welfare and achievement. A set of criteria for judging equality measures could be proposed as follows.

1. There should be an explicit concept of what equality means, which form of equality legislation is being espoused and what the indicators of success are.

2. There should be statutory requirements which result in a number of measures to promote equality.

3. As far as possible, equality measures should be understood and 'espoused' by the employees at all levels within an institution.

4. Resources of time, money and personnel need to be devoted to the promotion of equality goals.

5. The extent to which equality measures are successful needs to be monitored.

6. Success needs to be rewarded, failure sanctioned and achievement promoted in the pursuit of equality.

7. There should be feedback loops within the system to ensure that HEIs benefit from institutionalized learning and use their experiences of success and failure to improve their practices and even influence other HEIs or lawmakers.

Although Tables 1-4 above seem to indicate that British female academics are progressing better than German female academics in the career stakes, there are many respects in which the German strategies conform to good practice. Gender equality is based upon a clear concept, that of 'gender mainstreaming', and is associated with sanctions to encourage compliance. The concept of 'mainstreaming' is also used in the UK (see Rees, 1998): the Equal Opportunities Commission has adopted mainstreaming as its central strategic approach to the development of equal opportunities in Britain (Rees, 1998, p. 190), but it is not as strongly and explicitly promulgated as in Germany and British approaches tend to be more pragmatic and piecemeal. In fact, Saunderson (2002, 2006, p. 194) claimed that although the Higher Education Funding Council for England asserts mainstreaming to be a fundamental principle, it is a nebulous concept for many academic workers. It would certainly strengthen equal opportunities to be based on a rational, well-grounded philosophy clearly distanced from flawed forms of ideology, such as positive discrimination. In Germany although HEIs vary in their commitment to equal opportunities, equality for female academics is rooted in fundamental social and constitutional values that in turn are embedded within the institutions. It is espoused by the government at the highest level and cascades down to grassroots levels within HEIs. All the major advisory and decision-making bodies have policies and publications on the promotion of women. The claim of 'democracy' for all includes equality for women, which in many respects has turned out to be quite a radical demand. Färber (2000, p. 262), in her case study of equality within the Free University of Berlin, concluded that the leadership and decision-making structures all meshed satisfactorily with senior management, Senate, Council/Court, subject departments, faculties and Women's Representatives to create favourable conditions 
0 for the promotion of equality. ${ }^{6}$ The pursuit of equality goals is backed by very considerable resources in Germany. Financial support packages for higher education, like HSP II (BLK, 1991), adopted promotion of female academics as one of the most central goals, and HSP III allocated $20 \%$ of its total sum for women's equality of opportunity and research on women (Kahlert, 2001). ${ }^{7}$ The amount spent on the promotion of equality increased from DM 3.2 million in 1985 to DM 21 million in 1997 (Bundesministerium für Familie, Senioren, Frauen und Jugend, 1998). Currently, under the HWP programme (2001-2006), €30 million are being spent on equal opportunities (Löther \& Mühlenbruch, 2004). The state exercises an important leadership and steering function in pursuance of equality 10 targets. Färber (2001, p. 152) believed this state role to be very important and hoped that it would not be dislodged by marketized deregulation.

Although European legislation like the Bologna Agreement (1999) manifests a commitment to reducing social and gender inequalities at both the national and at European levels, the results in terms of the number of females at the highest academic and management levels are still not very impressive in Germany. Counterreform forces are strong within the system. Equality is championed in the Basic Law, but the reality is very different. The Federal Government and public opinion made a great issue of gender equality in academia during the 1990s, but due to the resistance of universities, neither Länder governments nor the Federal Governments fully succeeded in implementing equality policies. When the financial programmes, such as HSP, stopped the universities did not in general continue their content. Overall, many professors are hostile to any forms of affirmative action in favour of women, arguing that this would be against the principle of academic excellence (Leistung) as the only acceptable criterion for access to a professorship. Women's representatives tend to be rejected as controversial if they are influential; only if they have no influence are they welcomed as giving a veneer of equal opportunity! There may be single universities where, as a result of historical conditions, the situation for women is slightly better. Such a specific historical case is the Free University of Berlin, which has a distinctive history of democracy among German universities. The same is true of the University of Frankfurt. Both universities have been leftist in political orientation and centres of student activism. These characteristics are important in influencing equality policies at both the HEI and Länder levels.

However, the most important reasons for inequality have to do with career structure and credentialism. As we have already seen, it is possible to rise to the very highest level within the British system on the basis of proven competence rather than qualifications. The German system is the polar opposite in its insistence upon the prerequisite qualification for each job level. The reunified Germany lacks permanent middle ranking posts such as Lecturer or Dozent that give security and help retain female academics within the system. It is ironic that the former East German higher education system actually had such a career structure and that it was discontinued after reunification (Pritchard, 1999, p. 201). Recently, however, major changes have been introduced in academic employment. The requirement for the Habilitation, so long a stumbling block to women in their child-bearing years, has been weakened 
and the career structure has been changed to include 'junior professors'. They are independent and are permitted to apply for research grants in their own right, rather than being subordinate to senior professors. They are the government's attempt to at last break free of the syndrome whereby its career academics only begin their jobs at age 40+ (Pritchard, 2006). These junior professors are allowed to hold posts for 6 years, after which time, if they have not attained a full professorship, they will have to leave the university. The introduction of junior professors is intended to benefit both men and women, but this attempt at remediation is still based on temporary employment which is vulnerable to financial cuts, and in order to create the new style professorships restructuring may do away with existing assistant posts and full professorships. Career reform is likely to be a palliative rather than a cure for the ills of German higher education and in the end may not do much to reduce gender inequality. Moreover, many young scholars are still doing their Habilitation as an 'insurance policy' to help them compete in the job market. What Krais et al. (1997) advocated almost a decade ago-a new staff structure-has still not arrived, although the government has tried hard to introduce it. The ladder for which she and her coauthors hoped still has not got enough steps and people still have to 'leap' rather than climb from relatively low to high positions, a recurrent problem for all, and most especially for women.

\section{Acknowledgements}

I am grateful to the following for their help with this paper: Dr Andrea Löther of the Centre of Excellence Women and Science, Bonn; Professor Dr Beate Krais of the Technical University, Darmstadt; Ms Charlotte Nielsen of the Association for University Teachers; Ms Erica Halvorsen of the Equality Challenge Unit.

\section{Notes}

30 1. Some subjects, e.g. the humanities, demand a Habilitation more than others, e.g. engineering. It is possible to be given a Chair in Humanities or Social Sciences without having done a Habilitation, but this is exceptional.

2. Up to now in the FRG the differences only occurred for top ranking ('C4') professors, as the others did not have the opportunity to negotiate their salaries.

3. An Equality Assessment is already being carried out for the 2008 UK Research Assessment Exercise.

4. It should be noted that these representatives have been used in German universities since the 1980 s and are not the direct result of mainstreaming.

5. Zur Gleichstellungsrecht an Hochschulen (CEWS, Bonn, available online at www.cews.org/ cews/files/60/de/pdf_publik3.pdf, accessed 4 March 2006). Theoretically, the link between funding and gender equality is a powerful one, although models vary and sometimes attract only 'lip service'. Usually the proportion of funding earmarked for equality is about $5 \%$.

6. It should be pointed out that she was the Women's Representative there, so she was personally involved in what she was writing about.

7. The UK too spends on equality. As Halvorsen (2002b, p. 17) pointed out, HEFCE, the Committee of Vice Chancellors and Principals and the Standing Conference of Principals 
(SCOP) were set up to operate an Equal Opportunities Action Group in 2000 and had funding of $£ 2.5$ million for 5 years.

\section{References}

Association of University Teachers (AUT) (2005) The diverse academy: the pay and employment of academic and professional staff in UK higher education by gender and ethnicity (London, AUT).

Association of University Teachers (AUT) (2006a) Advancing equality for men and women-the AUT response to government proposals to introduce a public sector duty to promote gender equality (London, AUT).

Association of University Teachers (AUT) (2006b) Full-time academic staff: gender pay gap by institution 2003-4 (London, AUT).

Bagilhole, B. (1993) How to keep a good woman down: an investigation of the role of institutional factors in the process of discrimination against women academics, British fournal of Sociology of Education, 14(3), 261-274.

Bagilhole, B. (2001) Attempting to break the glass ceiling, in: B. Geissel \& B. Seeman (Eds) Bildungspolitik und Geschlecht: ein europäischer Vergleich (Opladen, Germany, Leske and Budrich), 189-2001.

Bagilhole, B. (2002) Against the odds: women academics' research opportunities, in: G. Howe \& A. Tauchert (Eds) Gender, teaching and research in higher education: challenges for the 21st century (Aldershot, UK, Ashgate), 46-56.

Bebbington, D. (2002) Women in science, engineering and technology: a review of the issues, Higher Education Quarterly, 56(4), 360-375.

Belensky, M. F., Clinchy, B. M., Goldberger, N. R. \& Tarule, J. M. (1986) Women's ways of knowing (New York, Basic Books).

Bett Report (1999) Independent review of higher education pay and conditions (London, Her Majesty's Stationery Office).

Bologna Agreement (1999) The European higher education area: joint declaration of the European Ministers of Education convened in Bologna on fune 19, 1999. Available online at: www.adriatico.unian.it/ravenna_dic2000/documenti/bologna.htm (accessed 27 June 2007).

ourdieu, P. (1994) Social space and symbolic power, in: P. Bourdieu (Ed.) In other words (Cambridge, UK, Polity Press), 122-139.

Bradley, H. (1996) Fractured identities: changing patterns of inequality (Cambridge, UK, Polity Press).

Brooks, A. (1997) Academic women (Buckingham UK, Society for Research into Higher Education and Open University Press).

Bund-Länder-Kommission (BLK) (1991) Informationen zur Förderung von Frauen im Rahmen des Zweiten Hochschulsonderprogramms (HSPII) (Bonn, BLK).

Bundesministerium für Bildung und Forschung (BMBF) (2001) Women in education and research: gender mainstreaming (Bonn, BMBF).

Bundesministerium für Bildung und Wissensahaft (BMBF) (2002) More women at the top!, Gender mainstreaming in research facilities (Bonn, BMBF).

Bundesministerium für Familie, Senioren, Frauen und Jugend (BMFSFJ) (1998) Frauen in der Bundesrepublik Deutschland (Bonn, BMFSFJ).

Carson, L. (2001) Gender relations in higher education: exploring lecturers' perceptions of student evaluations of teaching, Research Papers in Education, 16(4), 337-358.

Centre for Excellence Women and Science (CEWS) (2006) Hochschulranking nach Gleichstellungsaspekten (Bonn, CEWS), 1-96.

Dalhoff, J., Lind, I. \& Löther, A. (2002) Gender mainstreaming, Wissenschaft und Forschung, Sozialwissenschaftlicher Informationsdienst, (1), 9-20.

Deem, R. (1981) State policy and ideology in the education of women, 1944-1980, British fournal of the Sociology of Education, 2(2), 131-143. 
0 Deutscher Bundestag (1998) Grundgesetz für die Bundesrepublik Deutschland (Berlin, Bundestag).

Deutscher Bundestag (2004) Federal framework act BGB1. I 2004, S. 3835 (????????, Bundestag).

Deutschlandvertrag (1990) Der Vertrag zur deutschen Einheit (Frankfurt am Main, Germany, Insel).

Entwistle, N. (2005) Learning outcomes and ways of thinking across contrasting disciplines and settings in higher education, The Curriculum fournal, 16(1), 67-82.

Färber, C. (2000) Frauenförderung an Hochschulen: neue Steuerungsinstrumente zur Gleichstellung (Frankfurt, Germany, Campus).

Färber, C. (2001) Neue Organisationsstrukturen im Hochschulsystem-eine Chance für Frauen?, in: B. Geissel \& B. Seeman (Eds) Bildungspolitik und Geschlecht: ein europäischer Vergleich (Opladen, Germany, Leske and Budrich), 135-153.

Greenfield, S., Peters, J., Rees, T. \& Samuels, G. (2002) SET fair: a report on women in science, engineering and technology (London, Department of Trade and Industry).

Halvorsen, E. (2002a) Female academics in a knowledge production society, Higher Education Quarterly, 56(4), 347-359.

Halvorsen, E. (2002b) Gender audit, in: G. Howe \& A. Tauchert (Eds) Gender, teaching and research in higher education: challenges for the 21st century (Aldershot, UK, Ashgate), 9-19.

Heward, C. (1994) Academic snakes and merit ladders: reconceptualising the 'glass ceiling', Gender and Education, 6(3), 249-262.

Hey, V. \& Bradford, S. (2004) The return of the repressed? The gender politics of emergent forms of professionalism in education, Fournal of Education Policy, 19(6), 691-713.

Heywood, A. (1992) Political Ideologies: an introduction (Basingstoke, UK, Macmillan).

Hunt, S. (2006) A message to AUT women on women, pay and the pay campaign, letter to AUT members.

Jackson, S. (2002) Transcending boundaries: women, research and teaching in the academy, in: G. Howe \& A. Tauchert (Eds) Gender, teaching and research in higher education: challenges for the 21st century (Aldershot, UK, Ashgate), 20-32.

Jones, A. (1993) Becoming a girl: post-structuralist suggestions for educational research, Gender and Education, 5(2), 157-166.

Kahlert, H. (2001) Geschlechtergerechtigkeit als Herausforderung der Studienreform, in: B. Geissel \& B. Seeman (Eds) Bildungspolitik und Geschlecht: ein europäischer Vergleich (Opladen, Germany, Leske and Budrich), 155-187.

Krais, B. (2002) Academia as a profession and the hierarchy of the sexes: paths out of research in German universities, Higher Education Quarterly, 56(4), 407-419.

Krais, B. (2006) Bourdieu's sociology of practice and the feminist debate on the gender 14 relationship, Theory, Culture and Society.

Krais, B., Krumpeter, T. \& Kraft, S. (October 1997) Wissenschaftskultur und weibliche Karrieren: zur Unterrepräsentanz von Wissenschaftlerinnen in der Max-Planck-Gesellschaft (Darmstadt, Germany, Max-Planck-Gesellschaft).

Loder, N. \& Eley, S. (1998) Probe into what puts women off research, The Times Higher Education 15 Supplement, 7.

35 Löther, A. \& Mühlenbruch, B. (2004) Gleichstellungspolitik in den Hochschulsonderprogrammen und im Hochschul- und Wissenschaftsprogramm, in:

A. Löther (Ed.) Erfolg und Wirksamkeit von Gleichstellungsmaßnahmen an Hochschulen (Bielefeld, Germany, Klein), 22-37.

Luttrell, W. (1989) Working-class women's ways of knowing: effects of gender, race, and class, Sociology of Education, 62, 33-46.

Morley, L. (2003) Quality and power in higher education (Maidenhead, UK, Society for Research into Higher Education and Open University Press).

Her Majesty's Government (1998) Northern Ireland act 1998 Chapter 47, Part VII, Human rights and equal opportunities. Available online at: www.opsi.gov.uk/ACTS/acts1998/80047i.htm\# end (accessed ?? ????????? ????). 
Office for Official Publications of the European Communities (2005) Eurostat yearbook (Luxembourg, Office for Official Publications of the European Communities).

Ong, W. (1981) Fighting for life: contest, sexuality and consciousness (Ithaca, NY, Cornell University Press).

Pritchard, R. M. O. (1999) Reconstructing education: East German schools and universities after unification (Oxford, UK, Berghahn).

Pritchard, R. M. O. (2003) Gender and education in east Germany after unification, in: E. Kolinsky \& H. M. Nickel (Eds) Reinventing gender (London, Frank Cass), 78-99.

Pritchard, R. M. O. (2006) Trends in the restructuring of German universities, Comparative Education Review, 50(1), 90-112.

Rees, T. (1998) Mainstreaming equality in the European union: education, training and labour market policies (London, Routledge).

10 Reybold, E. (2002) Pragmatic epistemology: ways of knowing as ways of being, International fournal of Lifelong Education, 21(6), 537-550.

Saunderson, W. (2002) Women, academic and identity: equal opportunities in the 'new managerialism' - a case of 'lipstick on the gorilla'?, Higher Education Quarterly, 56(4), 376-406.

Saunderson, W. (2006) Gender [in] equality in mass higher education: the need for change, in: I. McNay (Ed.) From mass to universal higher education: building on experience (???????????, UK, Society for Research into Higher Education and Open University Press).

Walkerdine, V. (1989) Counting girls out (London, Virago).

Walsh, V. (2002) Equal opportunities without 'equality': redeeming the irredeemable', in: G. Howe \& A. Tauchert (Eds) Gender, teaching and research in higher education: challenges for the 21st century (Aldershot, UK, Ashgate), 33-45.

West, J. \& Lyon, K. (1995) The trouble with equal opportunities: the case of women academics, Gender and Education, 7(1), 51-68.

Wilson, M. (1986) Report on the status of academic women in New Zealand (Wellington, New Zealand, Association of University Staff of New Zealand).

Wolffensperger, J. (1993) 'Science is truly a male world': the interconnectedness of knowledge, gender and power within university education, Gender and Education, 5(1), 37-54.

Yanoshak, N. \& Delplato, J. (1993) De-disciplining the disciplines: the suspect politics of interdisciplinary pedagogy, Gender and Education, 5(3), 283-288.

Yorke, M. (2006) Gold in them there hills? Extracting and using data from existing sources, Tertiary Education and Management, 12(3), 201-213.

Zentrum fur Umfragen, Methoden und Analysen (ZUMA) (2004) Zunehmende Tendenz zu späteren Geburten und Kinderlosigkeiten bei Akademikerinnen: eine Kohortenanalyse auf der Basis von Mikrozensusdaten (Mannheim, Germany, ZUMA).

Zimmer, A. (2003) Women in European universities final report 2000-2003 (?????????, Research and Training Network). Available online at: www.women-eu.de (accessed 3 June.2006). 